\title{
Comparative efficacy of silymarin and choline chloride (liver tonics) in preventing the effects of aflatoxin $B_{1}$ in bovine calves
}

\author{
O. Naseer', J.A. Khan', M.S. Khan'1, M.O. Omer' ${ }^{2}$, G.A. Chishti', \\ M.L. Sohail ${ }^{1}$, M.U. Saleem ${ }^{3}$ \\ ${ }^{1}$ Department of Clinical Medicine and Surgery, Faculty of Veterinary Sciences, UVAS Lahore, Pakistan \\ ${ }^{2}$ Department of Pharmacology and Toxicology, Faculty of Biosciences, UVAS Lahore, Pakistan \\ ${ }^{3}$ Department of Biosciences, Faculty of Veterinary Sciences, Bahauddin Zakariya University Multan, Pakistan
}

\begin{abstract}
Aflatoxins are secondary metabolites produced by Aspergillus spp. which are injurious to animals and humans The aim of this study was to determine the effects of aflatoxin $\mathrm{B}_{1}\left(\mathrm{AFB}_{1}\right)$ on Average Daily Feed Intake (ADFI), Average Daily Weight Gain (ADWG), haematological and serum biochemical responses of Bovine Calves and to determine the comparative efficacy of two different liver tonics against $\mathrm{AFB}_{1}$. Twenty seven calves were selected from herd and divided into 3 groups. All calves were fed with $1.0 \mathrm{mg} / \mathrm{kg} \mathrm{AFB}_{1}$ for a period of 10 days. After that they were fed with liver tonics: Silymarin fed at a rate of $600 \mathrm{mg} / \mathrm{kg}$ and Choline chloride $500 \mathrm{mg} / \mathrm{kg}$ for 7 days. The results indicate that the ADFI and ADWG of $\mathrm{AFB}_{1}$ treated calves decreased significantly. Serum levels of alanine aminotransferase (ALT), aspartate aminotransferase (AST), blood urea nitrogen (BUN) and creatinine significantly increased due to $\mathrm{AFB}_{1}$. In haematology the total erythrocyte count (TEC), total leukocyte count (TLC), haemoglobin concentration (HGB), haematocrit levels (HCT), mean corpuscular haemoglobin $(\mathrm{MCH})$, mean corpuscular volume (MCV) and mean corpuscular haemoglobin concentration (MCHC), lymphocyte \%, neutrophil \% and monocyte \% significantly decreased in $\mathrm{AFB}_{1}$ treated calves after 10 days of feeding. Both liver tonics significantly $(\mathrm{p}<0.05)$ improved all the parameters, including ADFI, ADWG, hematologial and serum biochemical test. However, Silymarin comparatively more efficiently ameliorate the effects induced by $\mathrm{AFB}_{1}$ than choline chloride.
\end{abstract}

Key words: silymarin, choline chloride, aflatoxin $B_{1}$, bovine calves 


\section{Introduction}

Currently, Pakistan is facing the challenge of mycotoxin contamination in feed (Sultana and Hanif, 2009, Anjum et al. 2012, Sultana et al. 2013). Aflatoxins are the most prevalent mycotoxins, and aflatoxin $\mathrm{B}_{1}\left(\mathrm{AFB}_{1}\right)$ is the most toxic (Abdel-Wahhab et al. 2002, Eraslan et al. 2006). According to a study in Pakistan, 97\% of samples of compound feed were contaminated with $\mathrm{AFB}_{1}$ and $52 \%$ of the positive $\mathrm{AFB}_{1}$ samples had a level greater than the maximum permitted level of European commission legislation (Sultana et al. 2013). Young calves and dairy cattle are both susceptible to $\mathrm{AFB}_{1}$ (Ko et al. 2015). Calves effected with aflatoxins display clinical signs of anorexia, jaundice, depression, submandibular edema, keratoconjuctivitis, photosensitization of unpigmented skin, diarrhea and dysentery. Gross lesions show hemorrhages in subcutaneous tissues, lymph nodes, skeletal muscles, pericardium and beneath the epicardium and serosal layer of the alimentary tract. In a previous study, liver and carcass were pale due to jaundice. Microscopic examination of the liver revealed that hepatocytes were significantly enlarged, especially in the periportal areas. The cytoplasm of hepatocytes was finely vacuolated with fat. Serum enzymes of liver origin and bilirubin were elevated (Humphreys 1988, Umar et al. 2015).

An effective way to overcome the effects of mycotoxins is to use liver tonics which protect the liver damage. Silymarin (Silybum marianum), the polyphenolic fraction from Milk Thistle is used for hepatoprotection in humans (Flora et al. 1998, Jacobs et al. 2002, Fraschini et al. 2002, Ladas and Kelly, 2003, Wen et al. 2007) and demonstrated good protection in various toxic paradigms of experimental liver diseases in small laboratory animals (Radko and Cybulski 2007). Silymarin functions as an antioxidant, which absorbs and regulates the intracellular glutathione. In addition, Silymarin stabilizes and regulates the outer membrane permeability of the cell by preventing the mycotoxin from entering the liver. Silymarin promotes rRNA synthesis, which stimulates regeneration of the liver, prevents cirrhosis by transforming the liver stellate cells into myofibroblasts and absorb free radicals, ultimately resulting in liver protection (Fraschini et al. 2002).

Choline deficiency in humans causes hepatosteatosis (Fatty liver), due to lack of phosphatidylcholine which transforms excess triglyceride to lipoproteins in the liver. (Yao and Vance 1988, 1989, Zeisel et al. 1991, Buchman et al. 1995). Choline deficiency also causes liver damage by increasing serum aminotransferases which is a sensitive indicator of liver problems (Zeisel et al. 1991, Albright et al.
1996, 2005, Albright and Zeisel, 1997, Rahmani et al. 2012). Thus, choline chloride could be used to treat liver damage caused by $\mathrm{AFB}_{1}$. Taking into account all these facts our study was piloted with the goal to analyse the effect of Silymarin and Choline chloride to minimize the effect of $\mathrm{AFB}_{1}$ in liver cells on ADFI, ADWG, haematology and serum biochemistry in calves.

\section{Materials and Methods}

\section{Aflatoxin $B_{1}$}

$\mathrm{AFB}_{1}$ was obtained from Sigma-Aldrich (St Quentin Fallavier, France).

\section{Liver Tonics}

The liver tonics included Silymarin and Choline chloride. Silymarin was given at a dose of $600 \mathrm{mg} / \mathrm{kg}$ and choline chloride orally at $500 \mathrm{mg} / \mathrm{kg}$ for seven days.

\section{Experimental Trial}

The trial was conducted at Ravi Campus UVAS Pattoki. In this study, 27 bovine calves of any breed and age between 6 to 12 months of age were used. The experiment was started after a 7-day adaptation period. The animals were fed with $3 \%$ of body weight concentrate feed and water ad libitum. The calves were divided into three groups: $\mathrm{A}, \mathrm{B}$ and $\mathrm{C}$ each having 9 bovine calves. $1.0 \mathrm{mg} / \mathrm{kg}$ of aflatoxin $\mathrm{B}_{1}\left(\mathrm{AFB}_{1}\right)$ was fed daily for 10 days through gelatinized capsules. Liver tonics were then given for 7 days.

\section{Experimental parameters}

\section{Average Daily Feed Intake (ADFI) and Average Daily Weight Gain (ADWG)}

ADFI was determined by weighing feed offered and feed refused by the animals on dry matter basis and average daily weight gain (ADWG) was calculated on weekly basis.

\section{Haematology and serum biochemistry}

Blood and serum samples were collected from all 3 groups on day $0,3,5$ and 7 of the intoxication period 
Table 1. Mean \pm SEM of Average daily feed intake (kg/day) in Bovine Calves fed on $1.0 \mathrm{mg} / \mathrm{kg}$ aflatoxin B1 contaminated feed with two different liver tonics.

\begin{tabular}{ccccc}
\hline Days & A & B & C & P value \\
\hline 0 & Silymarin & Choline chloride & Control Positive & 0.08 \\
3 & $0.27 \pm 0.0543$ & $0.26 \pm 0.0576$ & $0.28 \pm 0.0532$ & 0.07 \\
5 & $0.30 \pm .0537$ & $0.32 \pm 0.0573$ & $0.33 \pm 0.0582$ & 0.00 \\
7 & $0.36 \pm 0.0582^{\mathrm{a}}$ & $0.35 \pm 0.0583^{\mathrm{b}}$ & $0.26 \pm 0.0654^{\mathrm{c}}$ & 0.00 \\
\hline
\end{tabular}

Table 2. Mean \pm SEM of Average daily weight gain $(\mathrm{kg} / \mathrm{day})$ in Bovine Calves fed on $1.0 \mathrm{mg} / \mathrm{kg}$ aflatoxin B1 contaminated feed with two different liver tonics.

\begin{tabular}{ccccc}
\hline Days & $\begin{array}{c}\text { A } \\
\text { Silymarin }\end{array}$ & $\begin{array}{c}\text { B } \\
\text { Choline chloride }\end{array}$ & $\begin{array}{c}\text { C } \\
\text { Control Positive }\end{array}$ & P value \\
\hline 0 & $0.34 \pm 0.0543$ & $0.36 \pm 0.0576$ & $0.38 \pm 0.0532$ & 0.08 \\
3 & $0.36 \pm .0537$ & $0.37 \pm 0.0573$ & $0.33 \pm 0.0582$ & 0.07 \\
5 & $0.40 \pm 0.0582^{\mathrm{a}}$ & $0.35 \pm 0.0583^{\mathrm{b}}$ & $0.26 \pm 0.0654^{\mathrm{c}}$ & 0.00 \\
7 & $0.43 \pm 0.0572^{\mathrm{a}}$ & $0.38 \pm 0.0532^{\mathrm{b}}$ & $0.24 \pm 0.0532^{\mathrm{c}}$ & 0.00 \\
\hline
\end{tabular}

(day 10). Serum levels for aspartate aminotransferase (AST), alanine transaminase (ALT), blood urea nitrogen (BUN) and creatinine were analysed by chemistry analyser (URIT-800), and haematology complete blood count (CBC) was determined by haematological analyzer (Abacus junior vet).

\section{Statistical Analysis}

The data -obtained was analysed statistically using Repeated measure ANOVA. Results with $\mathrm{p}<0.05$ are statistically significant.

\section{Results}

\section{Average Daily Feed Intake (kg/day; ADFI)}

Average daily feed intake reduced significantly due to $\mathrm{AFB}_{1}$. Silymarin and Choline chloride significantly increased the average daily feed intake from day 5 of treatment $(\mathrm{p}<0.05)$ but the group treated with Silymarin showed better progress and consumed $0.43 \pm 0.0572 \mathrm{~kg}$ feed on day 7 of treatment as compared to the Choline chloride and the control group (Table 1.

\section{Average Daily Weight Gain kg/day (ADWG)}

Average daily weight gain reduced significantly by feeding $\mathrm{AFB}_{1}$. Silymarin and Choline chloride improved the ADWG remarkably from day 5 of treatment $(\mathrm{p}<0.05)$ but Silymarin showed better results $0.43 \pm 0.0572 \mathrm{~kg}$ on day 7 of treatment as compared to the other groups (Table 2).

\section{Haematology and Serum Biochemistry}

$\mathrm{AFB}_{1}$ badly affects complete blood count (CBC) of calves. All the parameters of $\mathrm{CBC}$ were reduced significantly (Table 3). Silymarin and Choline chloride significantly improved the $\mathrm{CBC}$ from day 5 after treatment $(\mathrm{p}<0.05)$. In the liver function test $(\mathrm{LFT})$, two enzymes Alanine aminotransferase (AST) and aspartate aminotransferase (ALP) were raised by feeding aflatoxin contaminated feed, but liver tonics cured the liver function significantly $(p<0.05)$. Silymarin showed better results as compared to Choline chloride as shown in table 4. Creatinine and BUN were the two parameters which were studied in the renal function test. Creatinine and BUN both increased after feeding $\mathrm{AFB}_{1}$. After treatment significant decrease in both was seen $(p<0.05)$ : Silymarin showed more significant results than Choline chloride presented in Table 5.

\section{Discussion}

The present study showed decreased ADFI in response to $\mathrm{AFB}_{1}$ in calves, I may be due to the systemic stress caused by alteration in the levels of 
Table 3. Mean \pm SEM of hematological parameters in Bovine Calves fed on $1.0 \mathrm{mg} / \mathrm{kg}$ aflatoxin B1 contaminated feed with two different liver tonics.

\begin{tabular}{|c|c|c|c|c|c|}
\hline Parameters & Days & $\begin{array}{c}\text { A } \\
\text { Silymarin }\end{array}$ & $\begin{array}{c}\text { B } \\
\text { Choline chloride }\end{array}$ & $\begin{array}{c}\text { C } \\
\text { Control Positive }\end{array}$ & $P$ value \\
\hline \multirow{4}{*}{ RBCs $\left(10^{6} / \mu \mathrm{L}\right)$} & 0 & $3.08 \pm 0.01289$ & $3.05 \pm 0.01289$ & $3.06 \pm 0.01289$ & 0.08 \\
\hline & 3 & $5.35 \pm 0.02739$ & $5.35 \pm 0.04216$ & $3.32 \pm 0.04622$ & 0.07 \\
\hline & 5 & $6.84 \pm 0.02651^{\mathrm{b}}$ & $6.95 \pm 0.02915^{\mathrm{a}}$ & $3.06 \pm 0.02698^{c}$ & 0.00 \\
\hline & 7 & $7.98 \pm 0.02754^{\mathrm{a}}$ & $7.09 \pm 0.05491^{\mathrm{b}}$ & $2.61 \pm 0.02874^{c}$ & 0.00 \\
\hline \multirow{4}{*}{$\operatorname{HGB}(\mathrm{g} / \mathrm{dl})$} & 0 & $5.64 \pm 0.00824$ & $5.61 \pm 0.00824$ & $5.66 \pm 0.00824$ & 0.08 \\
\hline & 3 & $7.95 \pm 0.02915$ & $7.94 \pm 0.02651$ & $7.94 \pm 0.02539$ & 0.06 \\
\hline & 5 & $8.44 \pm 0.02991^{\mathrm{a}}$ & $7.75 \pm 0.02739^{\mathrm{b}}$ & $5.94 \pm 0.02789^{c}$ & 0.00 \\
\hline & 7 & $9.73 \pm 0.09921^{\mathrm{a}}$ & $8.43 \pm 0.02348^{\mathrm{b}}$ & $5.73 \pm 0.00913^{c}$ & 0.00 \\
\hline \multirow{4}{*}{$\mathrm{PCV}(\%)$} & 0 & $18.65 \pm 0.01027$ & $18.61 \pm 0.01027$ & $18.64 \pm 0.01027$ & 0.06 \\
\hline & 3 & $20.13 \pm 0.03951$ & $20.17 \pm 0.04613$ & $20.19 \pm 0.02571$ & 0.09 \\
\hline & 5 & $25.65 \pm 0.02739^{\mathrm{b}}$ & $26.94 \pm 0.02789^{\mathrm{a}}$ & $15.24 \pm 0.02784^{\mathrm{c}}$ & 0.00 \\
\hline & 7 & $25.98 \pm 0.09326^{\mathrm{b}}$ & $26.01 \pm 0.04381^{\mathrm{a}}$ & $13.17 \pm 0.01784^{\mathrm{c}}$ & 0.00 \\
\hline \multirow{4}{*}{ WBCs $\left(\times 10^{3} / \mu \mathrm{l}\right)$} & 0 & $3.86 \pm 0.2783$ & $3.84 \pm 0.1843$ & $3.89 \pm 0.1839$ & 0.09 \\
\hline & 3 & $3.90 \pm 0.0091$ & $3.87 \pm 0.0654$ & $3.86 \pm 0.00913$ & 0.07 \\
\hline & 5 & $4.14 \pm 0.0864^{\mathrm{b}}$ & $4,76 \pm 0.0256^{\mathrm{a}}$ & $3.70 \pm 0.0173^{c}$ & 0.00 \\
\hline & 7 & $5.98 \pm 0.0852^{\mathrm{a}}$ & $5.87 \pm 0.0954^{\mathrm{b}}$ & $3.55 \pm 0.9854^{\mathrm{c}}$ & 0.00 \\
\hline \multirow{4}{*}{ Lymphocytes (\%) } & 0 & $58.95 \pm 0.0986$ & $58.94 \pm 0.0986$ & $58.93 \pm 0.0986$ & 0.07 \\
\hline & 3 & $56.14 \pm 0.0284$ & $56.16 \pm 0.0263$ & $56.18 \pm 0.0269$ & 0.08 \\
\hline & 5 & $61.95 \pm 0.0318^{\mathrm{b}}$ & $63.05 \pm 0.0277^{\mathrm{a}}$ & $37.35 \pm 0.0273^{c}$ & 0.00 \\
\hline & 7 & $61.74 \pm 0.0382^{\mathrm{b}}$ & $62.09 \pm 0.0472^{\mathrm{a}}$ & $18.46 \pm 0.0932^{\mathrm{c}}$ & 0.00 \\
\hline \multirow{4}{*}{ Monocytes (\%) } & 0 & $0.25 \pm 0.0931$ & $0.23 \pm 0.0931$ & $0.27 \pm 0.0931$ & 0.06 \\
\hline & 3 & $1.74 \pm 0.0278$ & $1.78 \pm 0.0275$ & $1.79 \pm 0.0266$ & 0.09 \\
\hline & 5 & $9.25 \pm 0.0273^{\mathrm{b}}$ & $11.95 \pm 0.0273^{\mathrm{a}}$ & $1.86 \pm 0.0328^{c}$ & 0.00 \\
\hline & 7 & $12.01 \pm 0.0621^{\mathrm{b}}$ & $14.07 \pm 0.0064^{\mathrm{a}}$ & $1.96 \pm 0.0063^{\mathrm{c}}$ & 0.00 \\
\hline \multirow{4}{*}{ Neutrophils (\%) } & 0 & $3.90 \pm 0.0913$ & $3.93 \pm 0.0913$ & $3.95 \pm 0.0913$ & 0.08 \\
\hline & 3 & $5.46 \pm 0.0312$ & $5.45 \pm 0.03296$ & $5.46 \pm 0.0273$ & 0.06 \\
\hline & 5 & $13.25 \pm 0.0271^{\mathrm{b}}$ & $16.75 \pm 0.0273^{\mathrm{a}}$ & $5.94 \pm 0.0289^{c}$ & 0.00 \\
\hline & 7 & $15.94 \pm 0.0095^{\mathrm{b}}$ & $17.97 \pm 0.0127^{\mathrm{a}}$ & $5.01 \pm 0.0213^{c}$ & 0.00 \\
\hline \multirow{4}{*}{$\operatorname{MCV}(\mathrm{fl})$} & 0 & $35.32 \pm 0.0913$ & $35.33 \pm 0.0913$ & $35.35 \pm 0.0913$ & 0.09 \\
\hline & 3 & $37.05 \pm 0.0277$ & $37.03 \pm 0.0273$ & $37.07 \pm 0.0318$ & 0.06 \\
\hline & 5 & $43.74 \pm 0.0307^{\mathrm{b}}$ & $46.25 \pm 0.0271^{\mathrm{a}}$ & $33.85 \pm 0.0308^{c}$ & 0.00 \\
\hline & 7 & $48.99 \pm 0.0342^{\mathrm{a}}$ & $45.54 \pm 0.0054^{\mathrm{b}}$ & $32.90 \pm 0.0087^{c}$ & 0.00 \\
\hline \multirow{4}{*}{$\mathrm{MCH}(\mathrm{pg})$} & 0 & $9.22 \pm 0.0126$ & $9.20 \pm 0.0126$ & $9.23 \pm 0.0126$ & 0.07 \\
\hline & 3 & $10.95 \pm 0.0275$ & $10.94 \pm 0.0243$ & $10.96 \pm 0.0300$ & 0.09 \\
\hline & 5 & $29.14 \pm 0.0284^{\mathrm{b}}$ & $31.85 \pm 0.0273^{\mathrm{a}}$ & $8.14 \pm 0.0269^{c}$ & 0.00 \\
\hline & 7 & $34.97 \pm 0.0093^{\mathrm{a}}$ & $33.65 \pm 0.0053^{\mathrm{b}}$ & $8.06 \pm 0.0653^{\mathrm{c}}$ & 0.00 \\
\hline \multirow{4}{*}{$\operatorname{MCHC}(\mathrm{g} / \mathrm{dl})$} & 0 & $22.92 \pm 0.0913$ & $22.94 \pm 0.0913$ & $22.95 \pm 0.0913$ & 0.06 \\
\hline & 3 & $25.15 \pm 0.0264$ & $25.14 \pm 0.0247$ & $25.16 \pm 0.0283$ & 0.08 \\
\hline & 5 & $27.94 \pm 0.0281^{\mathrm{b}}$ & $30.84 \pm 0.0275^{\mathrm{a}}$ & $25.04 \pm 0.0245^{\mathrm{c}}$ & 0.00 \\
\hline & 7 & $33.07 \pm 0.0043^{\mathrm{a}}$ & $31.95 \pm 0.0548^{\mathrm{b}}$ & $25.65 \pm 0.0327^{c}$ & 0.00 \\
\hline
\end{tabular}

Table 4. Mean \pm SEM of alanine Aminotransferase $(\mathrm{u} / \mathrm{L})$ and Aspartate aminotransferase $(\mathrm{u} / \mathrm{L})$ in Bovine Calves fed on 1.0 $\mathrm{mg} / \mathrm{kg}$ aflatoxin $\mathrm{B} 1$ contaminated feed with two different liver tonics.

\begin{tabular}{cccccc}
\hline Parameters & Days & Silymarin & Choline chloride & $\begin{array}{c}\text { Control } \\
\text { (Diseased animals) }\end{array}$ & P value \\
\hline & 0 & $38.15 \pm 0.0256$ & $38.17 \pm 0.0256$ & $38.19 \pm 0.0256$ & 0.09 \\
Alanine aminotransferase $(\mathrm{u} / \mathrm{L})$ & 3 & $37.04 \pm 0.0269$ & $37.05 \pm 0.0273$ & $37.04 \pm 0.0281$ & 0.07 \\
& 5 & $31.74 \pm 0.0266^{\mathrm{a}}$ & $30.44 \pm 0.0287^{\mathrm{c}}$ & $38.94 \pm 0.0281^{\mathrm{a}}$ & 0.00 \\
& 7 & $24.08 \pm 0.0237^{\mathrm{a}}$ & $23.01 \pm 0.0269^{\mathrm{c}}$ & $38.90 \pm 0.0091^{\mathrm{a}}$ & 0.00 \\
\hline & 0 & $98.61 \pm 0.0953$ & $98.68 \pm 0.0953$ & $98.69 \pm 0.0953$ & 0.06 \\
Aspartate aminotransferase $(\mathrm{u} / \mathrm{L})$ & 3 & $95.94 \pm 0.0281$ & $95.95 \pm 0.0273$ & $95.93 \pm 0.0273$ & 0.08 \\
& 5 & $65.45 \pm 0.0258^{\mathrm{a}}$ & $65.34 \pm 0.0272^{\mathrm{c}}$ & $95.74 \pm 0.0266^{\mathrm{a}}$ & 0.00 \\
& 7 & $53.20 \pm 0.0276^{\mathrm{a}}$ & $52.96 \pm 0.0047^{\mathrm{c}}$ & $97.29 \pm 0.0217^{\mathrm{a}}$ & 0.00 \\
\hline
\end{tabular}


Table 5. Mean \pm SEM of Creatinine $(\mathrm{mg} / \mathrm{dl})$ and BUN $(\mathrm{mg} / \mathrm{dl})$ in Bovine Calves fed on $1.0 \mathrm{mg} / \mathrm{kg}$ aflatoxin B1 contaminated feed with two different liver tonics.

\begin{tabular}{cccccc}
\hline Parameters & Days & Silymarin & Choline chloride & $\begin{array}{c}\text { Control } \\
\text { (Diseased animals) }\end{array}$ & P value \\
\hline & 0 & $2.95 \pm 0.0643$ & $2.93 \pm 0.0643$ & $2.92 \pm 0.0643$ & 0.07 \\
Creatinine (mg/dl) & 3 & $2.85 \pm 0.0258$ & $2.84 \pm 0.0280$ & $2.86 \pm 0.0411$ & 0.09 \\
& 5 & $2.35 \pm 0.0273^{\mathrm{b}}$ & $1.95 \pm 0.0273^{\mathrm{c}}$ & $2.74 \pm 0.0287^{\mathrm{a}}$ & 0.00 \\
& 7 & $1.75 \pm 0.0274^{\mathrm{b}}$ & $1.47 \pm 0.0376^{\mathrm{c}}$ & $2.90 \pm 0.0279^{\mathrm{a}}$ & 0.00 \\
\hline & 0 & $26.81 \pm 0.0052$ & $26.88 \pm 0.0052$ & $26.85 \pm 0.0052$ & 0.07 \\
BUN (mg/dl) & 3 & $25.35 \pm 0.0273$ & $25.36 \pm 0.0411$ & $25.33 \pm 0.0273$ & 0.09 \\
& 5 & $23.65 \pm 0.0273^{\mathrm{b}}$ & $22.74 \pm 0.0266^{\mathrm{c}}$ & $26.65 \pm 0.0273^{\mathrm{a}}$ & 0.00 \\
& 7 & $14.01 \pm 0.0276^{\mathrm{c}}$ & $16.39 \pm 0.0282^{\mathrm{b}}$ & $27.90 \pm 0.0387^{\mathrm{a}}$ & 0.00 \\
\hline
\end{tabular}

thyroxin $\left(\mathrm{T}_{4}\right)$ and tri-iodothyronine $\left(\mathrm{T}_{3}\right)$ hormones, due to which the liver metabolism is interrupted (Royes and Yanong, 2002). These findings are in accordance with the results of Jones and Ewart (Jones and Ewart, 1979) who stated that $\mathrm{AFB}_{1}$ contaminated diet $(0.02 \mathrm{mg} / \mathrm{kg})$ reduced ADFI in Friesian cattle. Similarly our results are in line with the findings of Pasha (2008) and Akhtar et al. (2014), who described a significant decrease in feed intake of Sahiwal dairy cows and Nilli Ravi buffaloes by feeding 500ppb $\mathrm{AFB}_{1}$ contaminated feed respectively. Our results show that the damaging effects of $\mathrm{AFB}_{1}$ on feed intake were recovered by the use of Silymarin and Choline chloride. This could be due to the hepatoprotective effects of both liver tonics. Silymarin has cytoprotective effects due to its free radical scavenging and antioxidant characters. Silymarin also has the ability to interact directly with the components of the cell membrane to avoid any abnormalities in the substance of lipid fractions responsible for conserving normal fluidity (Muriel and Mourelle, 1990). It can also enter the nucleus and act on the polymerase I enzyme of RNA and on the transcription of rRNA, causing in increased formation of ribosomes, and in turn accelerates protein and DNA synthesis (Sonnenbichler and Zetl, 1986), thus leading to an increase in the synthesis of structural and functional proteins which ultimately repair the damaged hepatocytes. Silymarin also stops inflammation by inhibiting the 5-lipoxygenase pathway. Choline chloride has a beneficial effect in reducing the fat from the liver, as fat filled vacuoles in the cytoplasm were seen in calves affected with $\mathrm{AFB}_{1}$. Choline is effective in fatty liver diseases caused by a shortage of highly unsaturated phospholipids. Choline is also the cofactor vital for the formation of such phospholipids (Humphreys, 1988) Both liver tonics effectively cured the calves but Silymarin was more efficient.

The present study shows a decrease in ADWG in calves affected with aflatoxins which is in line with Lynch (Lynch et al. 1972) whose study also noted the weight loss in calves. Silymarin showed more efficient results in improving the weight gain than choline chloride. Our results demonstrated an increase in the plasma serum level of AST, ALT, serum creatinine and BUN levels of calves: the increase in these components presented hepatotoxic effect of $\mathrm{AFB}_{1}$ in terms of liver damage and ultimate enzyme release into the blood circulatory system. This is in agreement with the conclusions of Bintvihok and Kositcharoenkul (2006) and Akhtar et al. (2014) who described increased levels of liver enzymes due to aflatoxin. Bingol et al. (2007) stated that there was no association between AST and aflatoxin concentration in goats instead there was a negative correlation between ALT activity and aflatoxin. Moreover, the findings of our study contradict the results of a study of Holstein cows (fed on experimentally impure $\mathrm{AFB}_{1}$ contaminated diet at dose rate of $13 \mathrm{mg}$ for 7 days), in which no change in AST and ALT was observed (Applebaum and Marth 1983). Of the two toxin binders, Silymarin was more efficient in lowering the $\mathrm{AFB}_{1}$ induced serum enzymes, creatinine and BUN than Choline chloride. This may be due to its anti-inflammatory, anti-oxidant, anti-fibrotic, anti- carcinogenic, anti-lipid peroxidative, membrane stabilizing properties and liver regenerating mechanisms (Radko and Cybulski, 2007).

The present study revealed that $\mathrm{AFB}_{1}$ effected calves showed highly decreased TEC, TLC, HGB, HCT, Lymphocytes \%, Neutrophils \%, Monocytes \%, $\mathrm{MCV}, \mathrm{MCH}$ and MCHC. These outcomes were in line with the results of other studies which explained haematopoiesis suppression by aflatoxins (Oguz et al. 2003). This decrease in haematological factors may be due to many causes such as decrease in iron binding capacity (Abdel-Wahhab et al. 2002) and hematopoietic defects in blood cells induced by aflatoxins. The haematological results of the present study are in agreement with the studies of Donmez et al. (2012) who reported decreased levels of TEC, TLC, HCT and $\mathrm{HGB}$ in rams fed on as $\mathrm{AFB}_{1}(250 \mu \mathrm{g})$ con- 
taminated diet. Of the two liver tonics, Silymarin worked more efficiently than choline chloride in treating the effects induced by $\mathrm{AFB}_{1}$.

The present study has elucidated the adverse effects of $\mathrm{AFB}_{1}$ on $\mathrm{ADFI}, \mathrm{ADWG}$, haematological and serum biochemical parameters related to the liver and kidney in calves. Of the two liver tonics, Silymarin showed more ameliorating effects than Choline chloride but both recovered the calves significantly from $\mathrm{AFB}_{1}$ damage. However, further studies are needed in order to investigate more fully the $\mathrm{AFB}_{1}$ effect and to explore the protective efficacy of liver tonics in calves. This is preliminary data about aflatoxin treatment, and further study to better understand the pharmacodynamics of Silymarin and Choline chloride and their distribution in respective tissues will prove to be a gateway to treatment of aflatoxin $\mathrm{B}_{1}$.

\section{Acknowledgements}

This work was financially supported by the Higher Education Commission (HEC), Islamabad, Pakistan under the Indigenous PhD fellowship program, PIN no. 112-22340-2AV1-034

\section{References}

Abdel-Wahhab MA, Nada SA, Khalil FA (2002) Physiological and toxicological responses in rats fed aflatoxin-contaminated diet with or without sorbent materials. Anim Feed Sci Tech 97: 209-219.

Akhtar R, Sardar M, Saima N, Saleem G, Imran S, Aslam A (2014) Response of Nili-Ravi buffalo to aflatoxins $B_{1}$ with and without toxin adsorbents. J Anim Feed Sci 23: 317-323.

Albright CD, Lui R, Bethea TC, Da Costa KA, Salganik RI, Zeisel SH (1996) Choline deficiency induces apoptosis in SV40-immortalized CWSV-1 rat hepatocytes in culture. FASEB J 10: 510-516.

Albright CD, Zeisel SH (1997) Choline deficiency causes increased localization of transforming growth factor- $\beta_{1}$ signaling proteins and apoptosis in the rat liver. Pathobiology 65: 264-270.

Albright CD, da Costa KA, Craciunescu CN, Klem E, Mar MH, Zeisel SH (2005) Regulation of choline deficiency apoptosis by epidermal growth factor in CWSV-1 rat hepatocytes. Cell Physiol Biochem 15: 59-68.

Anjum MA, Khan SH, Sahota AW, Sardar R (2012) Assessment of Aflatoxin $B_{1}$ in Commercial Poultry Feed and Feed Ingredients. J Anim Plant Sci 22 (2): 268-272.

Applebaum RS, Marth EH (1983) Responses of dairy cows to dietary aflatoxin: Concentration of blood serum constituents and hormones associated with liver-kidney dysfunction and maintenance of lactation. Eur J Appl Microbiol 18: 381-386.

Bingol NT, Tanritanir P, Dede S, Ceylan E (2007) Influence of aflatoxin present in forages and concentrated feedin- gstuffs on milk and some serum biochemical parameters in goats. Bull. Vet Inst Pulawy 51: 65-69.

Bintvihok A, Kositcharoenkul S (2006) Effect of dietary calcium propionate on performance, hepatic enzyme activities and aflatoxin residues in broilers fed a diet containing low levels of aflatoxin $\mathrm{B}_{1}$. Toxicon 47: 41-46.

Buchman A, Dubin M, Moukarzel A, Jenden D, Roch M (1995) Choline deficiency: a cause of hepatic steatosis during parenteral nutrition that can be reversed with intravenous choline supplementation. Hepatology 22: 1399-1403.

Donmez N, Donmez HH, Keskin E, Kisadere I (2012) Effects of aflatoxin on some haematological parameters and protective effectiveness of esterified glucomannan in Merino rams. Sci World J 2012: 342-468.

Eraslan G, Akdogan M, Liman BC, Kanbur M, Delibas N (2006) Effects of dietary aflatoxin and hydrated sodium calcium aluminosilicate on triiodothyronine, thyroxin thyrotrophin and testosterone levels in quails. Turk J Vet Anim Sci 30: 41-45.

Flora K, Hahn M, Rosen H, Benner K (1998) Milk thistle (Silybum marianum) for the therapy of liver disease. Am J Gastroenterol 93: 139- 143.

Fraschini F, Demartini G, Esposti D (2002) Pharmacology of silymarin. Clin Drug Invest 22: 51-65.

Humphreys DJ (1988) Veterinary toxicology. $3^{\text {rd }}$ ed., Bailiere Trindell, London. pp. 157.

Jacobs BP, Dennehy C, Ramirez G, Sapp J, Lawrence VA (2002) Milk thistle for the treatment of liver disease: a systematic review and meta-analysis. Am $\mathrm{J}$ Med 113: 506-15.

Jones MG, Ewart JM (1979) Effects on milk production associated with consumption of decorticated extracted groundnut meal contaminated with aflatoxin. Vet Rec 105: 492-493.

Ko J, Lee C, Choo J (2015) Highly sensitive SERS-based immunoassay of aflatoxin $\mathrm{B}_{1}$ using silica-encapsulated hollow gold nanoparticles. J Hazard Mater 285: 11-17.

Ladas EJ, Kelly KM (2003) Milk thistle: is there a role for its use as an adjunct therapy in patients with cancer? J Altern Complement Med 9: 411- 416.

Lynch GP, Covey FT, Smith DF, Weinland BT (1972) Response of Calves to a Single Dose of Aflatoxin. J Anim Sci 35: 65-68.

Muriel P, Mourelle M (1990) Prevention by silymarin of membrane alterations in acute $\mathrm{CCl} 4$ liver damage. J Appl Toxicol 10 (4): 275-279.

Oguz H, Hadimli HH, Kurtoglu V, Erganis O (2003) Evaluation of humoral immunity of broilers during chronic aflatoxin (50 and $100 \mathrm{ppb}$ ) and clinoptilolite exposure. Revue Med Vet 154: 483-486.

Pasha TN (2008) Detoxification of aflatoxin by yeast sludge in the feed of dairy cattle and its impact on increased milk production. IJAVMS 2: 18-26.

Radko L, Cybulski W (2007) Application of silymarin in human and animal medicine. JPCCR 1: 022-026.

Rahmani MG, Kamalyan RG, Dehghan-Banadaky MJ, Marmaryan GYU (2012) The effect of oral administration of choline on some liver function characterized blood plasma enzymes of early lactating dairy cows. Biol J Arme 3: $83-86$

Royes JB and Yanong RP (2002) Molds in fish feeds and aflatoxicosis. University of Florida, Institute of Agricultural Sciences, pp 1-4. 
Sonnenbichler J, Zetl I (1986) Biochemical effects of the flavonolignane silibinin on RNA, protein and DNA synthesis in rat livers. Prog Clin Biol Res 213: 319-331.

Sultana N, Hanif NQ (2009) Mycotoxin contamination in cattle feed and feed ingredients. Pak Vet J 29: 211-213.

Sultana N, Rashid A, Tahira I, Hanif HU, Hanif NQ (2013) Distribution of various mycotoxins in compound feed, total mix ration and silage. Pak Vet J 33: 200-204.

Umar S, Munir MT, Shah MA, Shahzad M, Khan RA, Sohoo MUR, Khan AU, Ameen K, Rafia-Munir A, Saleem F (2015) Outbreak of aflatoxicosis on a local cattle farm in Pakistan. Veterinaria 3: 13-17.

Wen Z, Dumas TE, Schrieber SJ, Hawke RL, Fried MW, Smith PC (2007) Pharmacokinetics and Metabolic Pro- file of Free, Conjugated, and Total Silymarin Flavonolignans in Human Plasma after Oral Administration of Milk Thistle Extract. Drug Metab Dispos 36: 65-72.

Yao ZM, Vance DE (1988) The active synthesis of phosphatidylcholine is required for very low density lipoprotein secretion from rat hepatocytes. J Biol Chem 263: 2998-3004.

Yao ZM, Vance DE (1989) Head group specificity in the requirement of phosphatidylcholine biosynthesis for very low density lipoprotein secretion from cultured hepatocytes. J Biol Chem 264: 11373-11380.

Zeisel SH, Da Costa KA, Franklin PD, Alexander EA, Lamont JT, Sheard NF, Beiser A. (1991) Choline, an essential nutrient for humans. FASEB J 5: 2093-2098. 